\title{
Analisis Kelengkapan Berkas Rekam Medis Pasien Rawat Inap Kasus Thypoid dalam Klaim BPJS dengan Metode Hatta
}

\author{
Suci Khotimah', Imas Masturoh ${ }^{2}$ \\ ${ }_{1,2}$ Poltekkes Kemenkes Tasikmalaya \\ Khotimahsuci2@gmail.com ${ }^{1}$, imas.mth74@gmail.com ${ }^{2}$
}

\begin{abstract}
Badan Penyelenggara Jaminan Sosial (BPJS) in Law Number 24 of 2011 described as a legal entity established to organize a social security program. The issue of BPJS insurance claims of one of the thypoid cases included in the top 10 diseases dropped claim guarantees, due to major or secondary diagnosis discrepancies with inspection evidence, will greatly affect the amount of insurance claims filed and received by the hospital. This causes a loss to the hospital resulting from the incomplete filling of medical record documents. The purpose of this study to determine how complete files patient hospital medical record the case of thypoid in claims BPJS Hatta method in hospital Jasa Kartini Tasikmalaya 2016. Methode study Descriptive. 95 document for sample use paper ceklsist. Result study The completeness of administrative analysis with percentage of $100 \%$ of the documents as claimed and not in accordance with the clarity statement of the problem and condition or diagnosis, informed consent, current, ink and information in charge, $98.5 \%(n=65)$ consistent inpu \& $7 \%(n=30)$ consistent input, service reason, unreadable text, standard abbreviation. The highest completeness of medical analysis based on extra information with 100\% "yes" percentage of complaint statement, electrolyte fluid dispensing, medical resume, primary and secondary diagnosis, "not the case" $(n=65) 78.5 \%$ and $(n=30) 76.7 \%$ are at risk of less than 3 years. It can be concluded that the percentage of completeness of administrative qualitative elements shows a high average percentage but there is still incompleteness in some elements. Percentage of completeness of medical qualitative analysis is following typhoid management seen from records regarding complaints and symptoms
\end{abstract}

Keyword : BPJS, Analisis, Analisis Kualitatif, Thypoid.

\begin{abstract}
Abstrak
Badan Penyelenggara Jaminan Sosial (BPJS) dalam Undang-Undang Nomor 24 Tahun 2011 dijelaskan merupakan badan hukum yang dibentuk untuk menyelenggarakan program jaminan sosial. Permasalahan klaim asuransi BPJS salah satu kasus thypoid yang temasuk dalam 10 besar penyakit turun jaminan klaim, karena ketidaksesuaian penulisan diagnosa utama atau sekunder dengan bukti pemeriksaan, akan sangat berpengaruh dengan besaran klaim asuransi yang diajukan dan diterima oleh rumah sakit. Hal ini menyebabkan kerugian terhadap rumah sakit akibat dari ketidak lengkapan pengisian dokumen rekam medis. Tujuan penelitian ini untuk mengetahui bagaimana kelengkapan berkas rekam medis pasien rawat inap kasus thypoid dalam klaim BPJS dengan metode Hatta di rumah sakit Jasa Kartini Tasikmalaya tahun 2016. Jenis penelitian yang digunakan Deskriptif, sampel 95 dokumen dengan pengisian lembar ceklis. Hasil penelitian kelengkapan analisis administratif dengan persentase $100 \%$ dokumen sesuai klaim dan tidak sesuai pada pernyataan kejelasan masalah dan kondisi atau diagnosis, informed consent, mutakhir, tinta dan informasi penanggung jawab, $98,5 \%(\mathrm{n}=65)$ masukan konsisten\&alasan pelayanan $96,7 \%(\mathrm{n}=30)$ masukan konsisten, alasan pelayanan, tulisan terbaca, singkatan baku. Kelengkapan tertinggi analisis medis berdasarkan informasi ekstra dengan keterangan"ya" persentase 100\% pada pernyataan keluhan, pemberia cairan elektrolit, resume medis, diagnosa utama dan sekunder, "bukan kasus ini" ( $\mathrm{n}=65) 78,5 \%$ dan $(\mathrm{n}=30) 76,7 \%$ usia beresiko kurang dari 3 tahun. Dapat disimpulkan bahwa persentase kelengkapan unsur analisis kualitatif administratif menunjukkan persentase rata-rata tinggi namun masih terdapat ketidaklengkapan di beberapa unsur. Persentase kelengkapan analisis kualitatif medis sudah sesuai dengan tatalaksana thypoid dilihat dari catatan mengenai keluhan dan gejala.
\end{abstract}

Kata kunci :BPJS, Analisis, Analisis Kualitatif, Thypoid. 


\section{PENDAHULUAN}

Berdasarkan Undang-Undang Republik Indonesia Nomor 44 Tahun 2009 Rumah sakit adalah institusi pelayanan kesehatan bagi masyarakat dengan karakteristik tersendiri yang dipengaruhi oleh perkembangan ilmu pengetahuan kesehatan, kemajuan teknologi, dan kehidupan sosial ekonomi masyarakat yang harus tetap mampu meningkatkan pelayanan yang lebih bermutu dan terjangkau oleh masyarakat agar terwujud derajat kesehatan yang setinggi-tingginya. Sesuai dengan hak dan kewajiban Rumah sakit dinyatakan sebagai tempat penyelenggaraan program pemerintah secara regional maupun nasional dengan Program Jaminan Kesehatan Sosial (Undang-Undang Republik Indonesia No. 44, 2009).

Peraturan Menteri Kesehatan Republik Indonesia Nomor 28 tahun 2014 Program Jaminan Kesehatan diwujudkan oleh pemerintah dengan meningkatkan derajat kesehatan masyarakat untuk mewujudkan kesejahteraan sosial dengan menyelenggarakan beberapa bentuk jaminan sosial di bidang kesehatan, diantaranya adalah melalui PT Askes (Persero) dan PT Jamsostek (Persero) yang melayani antara lain pegawai negeri sipil, penerima pensiun, veteran, dan pegawai swasta. Untuk masyarakat miskin dan tidak mampu, pemerintah memberikan jaminan melalui skema Jaminan Kesehatan Masyarakat (Jamkesmas) dan Jaminan Kesehatan Daerah (Jamkesda). Namun demikian, skemaskema tersebut masih terfragmentasi, terbagi-bagi sehingga biaya kesehatan dan mutu pelayanan menjadi sulit terkendali. Untuk mengatasi hal tersebut, terbitlah Undang-Undang Nomor 40 Tahun 2004 ini mengamanatkan bahwa program jaminan sosial wajib bagi seluruh penduduk termasuk program Jaminan Kesehatan melalui suatu Badan Penyelenggara Jaminan Sosial (BPJS) (Permenkes Republik Indonesia No. 28, 2014).

Badan Penyelenggara Jaminan Sosial (BPJS) dalam Undang-Undang Nomor 24 Tahun 2011 dijelaskan merupakan badan hukum yang dibentuk untuk menyelenggarakan program jaminan sosial, adapun bentuk perlindungannya adalah untuk menjamin seluruh rakyat agar dapat memenuhi kebutuhan dasar hidupnya dengan layak dibidang kesehatan agar masyarakat dapat memperoleh pelayanan kesehatan sesuai dengan indikasi medis, dengan biaya yang terjangkau (Undang-undang Republik Indonesia No. 24, 2011).
Salah satu komponen sumber daya yang diperlukan dalam menjalankan pembangunan kesehatan adalah pembiayaan kesehatan, pembiayaan kesehatan bersumber dari pemerintah dan pembiayaan yang bersumber dari masyarakat (Kemenkes Republik Indonesia, 2011). Program BPJS sebagai tindak lanjut dari pada Jaminan Kesehatan Nasional bertujuan untuk pembiayaan kesehatan, namun perlu dipahaminya oleh petugas kesehatan dan verifikasi klaim BPJS subsistem pembiayaan kesehatan. Namun kenyataan hal ini masih kurang dimengerti dan dipahami sepenuhnya dimana masih terdapat permasalahan antara pelayanan kesehatan yang diterima dengan tuntutan pengajuan klaim dan rumah sakit, yaitu pengajuan klaim tidak sesuai dengan prosedur dan tarif dalam Perjanjian Kerjasama (PKS) sehingga menimbulkan masalah(Malonda, T. dkk, 2011).

Masalah yang muncul antara lain adanya ketidaklengkapan dokumen klaim terutama pada rekapitulasi pelayanan dalam rekam medis dan berkas pendukung pasien yang merupakan sebagai dari kelengkapan dokumen dan prosedur klaim masalah tersebut muncul karena kurangnya pengetahuan dan pemahaman dari dokter, perawat, dan petugas rekam medik terhadap kelengkapan dokumen rekam medis (Malonda, T. dll : 2015). Dampak dari ketidaklengkapan tersebut menyebabkan terhambatnya proses klaim asuransi oleh pihak ketiga yaitu BPJS, karena ketidaksesuaian penulisan diagnosa utama atau disertai dengan diagnosa sekunder/tambahan, akan sangat berpengaruh dengan besaran klaim asuransi yang diajukan dan diterima oleh rumah sakit. Hal ini sejalan dengan penelitian Hana Abdullah yang menyatakan bahwa pembengkakan pembiayaan pelayanan kesehatan yang terjadi di RSI Sultan Agung pada tahun 2008 terindikasi klaim hanya ditunjukkan untuk diagnosa utama karena tercatat dalam data rekam medis sedangkan diagnosa sekunder/tambahan tidak mendapatkan ganti pembiayaan dari dana klaim sehingga menyebabkan pembiayaan kesehatan Jamkesmas membengkak dan memerlukan covering pembiayaan(Abdullah, 2013).

Covering terjadi karena tarif BPJS ditentukan menggunakan tarif INA-CBG's bukan menggunakan tarif rumah sakit sehingga jumlah klaim berdasarkan tarif rumah sakit terkadang berbeda dengan jumlah hasil klaim(Putra, 2016). Resiko apabila rumah sakit secara terus menerus menanggung selisih tarif INACBG's maka dampak yang terjadi yaitu cadangan 
dana yang dimiliki oleh rumah sakit menjadi semakin kecil dikarenakan pendapatan yang diterima juga semakin mengecil. Cadangan dana yang menipis akan berakibat pada perkembangan rumah sakit seperti pembangunan gedung, penggantian alat rusak, pengembangan layanan dan lainnya menjadi lambat (Putri, 2016). Covering pembiayaan terjadi akibat dari ketidaklengkapan dokumen, karena rekam medis seringkali merupakan satu-satunya catatan yang dapat memberikan informasi terinci tentang apa yang sudah terjadi selama pasien dirawat di rumah sakit(Abdullah, 2013).

Ketidaklengkapan dokumen yang sering terjadi diantaranya diantaranya pada kasus Thypoid, hal ini disebabkan karena tidak spesifiknya gejala kasus ini. Beberapa uji yang paling sensitivitas diantaranya uji tubex dengan sensitivitas 70\%-80\%, uji typhidot dengan sensitivitas $98 \%$, dan uji IgM dipstick terhadap Salmonella thypi dengan sensitivitas 6577\% (Sudoyo. at all, 2010) sedangkan untuk tes widal setiap rumah sakit mempunyai nilai standar tersendiri, maka dari itu tes widal tidak dapat dipakai untuk membantu menegakkan diagnosis demam thypoid bila dilakukan satu kali saja, kenaikan widal titer harus dilakukan beberapa kali uji widal dalam menegakkan diagnosis ini (Rampengan, 2008) namun pemeriksaan darah pada minggu 1 dengan metode pembiakan kuman akan lebih sensitifitas 80-90\% sebab paling tinggi pada minggu I sakit, diagnosis pasti demam thypoid (Tjokroprawiro. dkk, 2007 :295). Jumlah kasus Thypoid menurut World Health Organization (WHO) pada tahun 2009 kurang lebih terdapat 17 juta kasus Thypoid di seluruh dunia dengan insidensi 600.000, dengan kasus kematian tiap tahun Case Fatality Rate (CFR) $=3,5 \%$. Berdasarkan Laporan Ditjen Pelayanan Medis Departemen Kesehatan RI tahun 2008, demam thypoid menempati urutan ke 2 dari 10 penyakit terbanyak pasien rawat inap di Rumah Sakit di Indonesia dengan jumlah kasus 81.116 dengan proporsi 3,15\% (Depkes RI, 2009 dalam Nuruzza \& Syahrul, 2016).

Kasus penyakit thypoid tersebut selalu ada dan sering menempati 10 besar penyakit di berbagai rumah sakit. Bila dikaitkan dengan permasalahan klaim asuransi BPJS dan tidak spesifiknya gejala kasus. Hal ini sering menimbulkan ketidaksesuaian diagnosis utama dengan diagnosis yang ada pada dokumen rekam medis dengan hasil verifikasi. Ketidaksesuain kasus Thypoid dengan dokumen dalam klaim BPJS dapat diketahui dengan analisis kualitatif metode Hatta, tujuannya untuk mengetahui sejauh apa kualitas pelayanan medis yang diberikan kepada pasien berdasarkan pemanfaatan kelengkepan informasi medis dan untuk menghindari ketidak konsistenan maupun pelaggaran terhadap catatan yang berdampak pada hasil yang tidak akurat dan tidak lengkap (Hatta, 2013). Metoda Hatta terbukti dapat digunakan dalam menganalisis rekaman prosedur diagnostik, keterapian fisik dan keteknisian medis. Metoda Hatta bermanfaat pula dalam merubah pandangan bahwa audit medis hanya untuk tenaga medis. Selanjutnya analisis rekam kesehatan diagnosis maupun tindakan dapat dikerjakan oleh tenaga kesehatan terlatih non dokter, termasuk praktisi manajemen informasi kesehatan (perekam medis) (Hatta, 2015).

Berdasarkan hasil studi pendahuluan di rumah sakit Jasa Kartini pada bulan Februari 2017 dengan observasi dan wawancara kepada petugas rekam medis, didapatkan data Thypoid sebagai kasus tertinggi dalam 10 besar kasus rawat inap dengan jumlah kasus 11837 (8,46\% ) pada tahun 2016 dan masuk kedalam 10 kasus tertinggi yang di klaim oleh BPJS. Diagnosa klaim yang diajukan tidak sesuai dengan standar pemeriksaan penunjang diagnosa tersebut ataupun diagnosa sekunder yang diajukan hanya beberapa yang diklaim oleh BPJS. Menurut BPJS, data kasus thypoid pada bulan Januari-Maret pasien rawat inap dengan pembayaran BPJS berjumlah179 kasus dengan yang sesuai klaim berjumlah Rp.697.393.200 dan 38 kasus yang tidak sesuai klaim dengan kerugian berjumlah Rp.44.872.100dengan permasalahan yang terjadi pihak rumah sakit harus melakukan covering biaya akibat turunnya jaminan karena tarif yang digunakan adalah tarif INA-CBG's dan tidak menggunakan tarif rumah sakit, hal ini menyebabkan kerugian terhadap rumah sakit sehingga perlunya covering pembiayaan.

Berdasarkan latar belakang diatas, peneliti tertarik untuk meneliti lebih jauh tentang "Analisis Kelengkapan Berkas Rekam Medis Pasien Rawat Inap Kasus Thypoid dalam Klaim BPJS dengan Metode Hatta di Rumah Sakit Jasa Kartini Tasikmalaya Tahun 2016".

\section{METODE}

Jenis penelitian yang digunakan yaitu deskriptif dengan menggunakan analisis kualitatif administratif dan medis metode Hatta, Cara pengumpulan data melalui observasi terhadap 95 dokumen rekam 
medis pasien rawat inap kasus Thypoid. Teknik pengambilan sampel pada penelitian ini adalah total sampling sesuai jumlah berkas yang berhasil dilakukan klaim baik yang besarannya sesuai klaim ataupun yang tidak sesuai klaim. Cara pengumpulan data melalui observasi dengan instrumen lembar checklist. Analisis data dengan univariat dalam bentuk persentase.

\section{HASIL}

Analisis Kualitatif Administratif Kelengkapan Informasi Dokumen Rekam Medis Kasus Thypoid tahun 2016

Tabel. 1 Persentase Hasil Analisis Kualitatif Administratif Kelengkapan Informasi Dokumen Rekam Medis Kasus Thypoid tahun 2016

\begin{tabular}{|c|c|c|c|c|c|c|c|c|c|c|c|}
\hline \multirow{4}{*}{ No. } & \multirow{4}{*}{ Kelengkapan dan informasi } & \multirow{4}{*}{$\mathbf{n}$} & \multicolumn{4}{|c|}{ Sesuai klaim } & \multirow{4}{*}{$\mathbf{n}$} & \multirow{2}{*}{\multicolumn{4}{|c|}{$\begin{array}{c}\text { Tidak sesuai klaim } \\
\text { Presentase hasil } \\
\text { kelengkapan informasi }\end{array}$}} \\
\hline & & & \multicolumn{4}{|c|}{$\begin{array}{c}\text { Presentase hasil } \\
\text { kelengkapan informasi }\end{array}$} & & & & & \\
\hline & & & \multicolumn{2}{|c|}{ Ya } & \multicolumn{2}{|c|}{ Tidak } & & \multicolumn{2}{|c|}{ Ya } & \multicolumn{2}{|c|}{ Tidak } \\
\hline & & & f & $\%$ & f & $\%$ & & f & $\%$ & f & $\%$ \\
\hline 1. & Kejelasan masalah dan kondisi atau diagnosis & 65 & 65 & 100 & 0 & 0 & 30 & 30 & 100 & 0 & 0 \\
\hline 2. & Masukan konsisten & 65 & 64 & 99 & 1 & 1,5 & 30 & 29 & 96,7 & 1 & 3,3 \\
\hline 3. & Alasan pelayanan & 65 & 64 & 99 & 1 & 1,5 & 30 & 29 & 96,7 & 1 & 3,3 \\
\hline 4. & Informed concent & 65 & 65 & 100 & 0 & 0 & 30 & 30 & 100 & 0 & 0 \\
\hline \multirow[t]{8}{*}{5.} & Telaah rekaman & & & & & & & & & & \\
\hline & a. Mutakhir & 65 & 65 & 100 & 0 & 0 & 30 & 30 & 100 & 0 & 0 \\
\hline & b. Singkatan baku & 65 & 63 & 97 & 2 & 3,1 & 30 & 29 & 96,7 & 1 & 3,3 \\
\hline & c. Hindari sindiran & 65 & 0 & 0 & 65 & 100 & 30 & 0 & 0 & 30 & 100 \\
\hline & d. Pengisian tidak senjang & 65 & 64 & 99 & 1 & 1,5 & 30 & 20 & 66,7 & 10 & 33,3 \\
\hline & e. Tinta & 65 & 65 & 100 & 0 & 0 & 30 & 30 & 100 & 0 & 0 \\
\hline & f. Catatan jelas & 65 & 65 & 100 & 0 & 0 & 30 & 20 & 66,7 & 10 & 33,3 \\
\hline & g. Informasi ganti rugi & 65 & 0 & 0 & 65 & 100 & 30 & 0 & 0 & 30 & 100 \\
\hline 6. & Informasi penanggung biaya & 65 & 65 & 100 & 0 & 0 & 30 & 30 & 100 & 0 & 0 \\
\hline
\end{tabular}

Berdasarkan tabel.1 menunjukkan bahwa Kelengkapan informasi dokumen rekam medis sesuai klaim dan tidak sesuai klaim tertinggi yaitu item kejelasan masalah dan kondisi atau diagnosis, informed concent, telaah rekaman, dan informasi penanggung jawab masing-masing dengan keterangan lengkap sebesar $100 \%$. Disusul dengan item masukan konsisten dan alasan pelayanan memiliki kelengkapan yang sama yaitu sebesar $98,5 \%$ sesuai klaim dan $96,7 \%$ tidak sesuai klaim. Item kelengkapan informasi tulisan terbaca dengan persentase $89,2 \%$ dokumen sesuai klaim dan persentase $9,67 \%$ dokumen tidak sesuai klaim. Berikutnya untuk kelengkapan informasi singkatan baku dengan persentase $96,9 \%$ dokumen sesuai klaim dan persentase $96,7 \%$ dokumen tidak sesuai klaim. Berbeda dengan item informasi ganti rugi diperoleh ketidaklengkapan tertinggi dengan persentase $100 \%$ karena tidak ditemukannya pernyataan informasi ganti rugi. Berikutnya kelengkapan informasi pengisian tidak senjang dengan persentase $98,5 \%$ dokumen sesuai klaim dan persentase $66,7 \%$ dokumen tidak sesuai klaim.

\section{Analisis Kualitatif Medis Kelengkapan Informasi Dokumen Rekam Medis Kasus Thypoid tahun 2016}

Berdasarkan tabel. 2 dibawah ini menunjukkan bahwa pemanfaatan informasi berdasarkan penilaian typoid pada rekam medis sesuai klaim dengan skor 4 keterangan "ya" persentase tertinggi yaitu tentang pernyataan keluhan pasien dengan persentase $100 \%$ disusul dengan gejala $(93,8 \%)$, nadi $(80 \%)$, pernafasan $(55,4 \%)$, perubahan pola tidur $(36,9 \%)$, usia pasien $(20 \%)$, riwayat perawatan penyakit $(16,9 \%)$, penyakit kronis $(12,3 \%)$, status gizi dan riwayat pengobatan $(9,2 \%)$. Untuk skor 3 keterangan "bukan kasus ini" pada dokumen sesuai klaim dengan 
persentase tertinggi yaitu usia pasien sebesar 78,5\% dan terendah tentang gejala sebesar $10 \%$. Untuk skor 2 keterangan "tidak" pada dokumen sesuai klaim dan yang tidak sesuai klaim memperoleh persentase yang rendah. Terakhir untuk skor 1 keterangan
"TAK" pada dokumen sesuai klaim yang memiliki persentase tinggi sebesar 100\% yaitu: riwayat operasi, riwayat merokok, menggunakan narkoba dan alkohol, riwayat penyakit menular seksual, riwayat alergi obat.

Tabel.2 Persentase Hasil Analisis Kualitatif Medis berdasarkan penilaian Kasus Thypoid tahun 2016

\begin{tabular}{|c|c|c|c|c|c|c|c|c|c|c|c|c|c|c|c|c|c|c|c|}
\hline \multirow{3}{*}{ No. } & \multirow{3}{*}{$\begin{array}{c}\text { Uraian kelengkapan dan } \\
\text { informasi }\end{array}$} & \multirow{3}{*}{$\mathbf{n}$} & \multicolumn{8}{|c|}{ Sesuai klaim } & \multirow{3}{*}{$\mathbf{n}$} & \multicolumn{8}{|c|}{ Tidak sesuai klaim } \\
\hline & & & \multicolumn{2}{|c|}{ Ya (4) } & \multicolumn{2}{|c|}{$\begin{array}{l}\text { Bukan } \\
\text { kasus ini } \\
\text { (3) }\end{array}$} & \multicolumn{2}{|c|}{$\begin{array}{l}\text { Tidak } \\
\text { (2) }\end{array}$} & \multicolumn{2}{|c|}{ TAK (1) } & & \multicolumn{2}{|c|}{ Ya (4) } & \multicolumn{2}{|c|}{$\begin{array}{l}\text { Bukan } \\
\text { kasus ini } \\
\quad(3)\end{array}$} & \multicolumn{2}{|c|}{$\begin{array}{l}\text { Tidak } \\
(2)\end{array}$} & \multicolumn{2}{|c|}{ TAK (1) } \\
\hline & & & f & $\%$ & f & $\%$ & f & $\%$ & f & $\%$ & & f & $\%$ & f & $\%$ & f & $\%$ & f & $\%$ \\
\hline \multirow[t]{15}{*}{ A. } & Penilaian pasien thypoid & & & & & & & & & & & & & & & & & & \\
\hline & 1. Keluhan pasien & 65 & 65 & 100 & 0 & 0 & 0 & 0 & 0 & 0 & 30 & 30 & 100 & 0 & 0 & 0 & 0 & 0 & 0 \\
\hline & 2. Riwayat perawatan penyakit & 65 & 11 & 16,5 & 0 & 0 & 0 & 0 & 54 & 83,1 & 30 & 5 & 16,7 & 0 & 0 & 1 & 1,5 & 24 & 80 \\
\hline & 3. Riwayat penyakit kronis & 65 & 8 & 12,3 & 0 & 0 & 0 & 0 & 57 & 87,7 & 30 & 3 & 10 & 0 & 0 & 0 & 0 & 27 & 90 \\
\hline & 4. Usia pasien & 65 & 13 & 20 & 51 & 78,5 & 0 & 0 & 1 & 1,5 & 30 & 5 & 16,7 & 23 & 76,7 & 0 & 0 & 2 & 6,7 \\
\hline & 5. Gejala & 65 & 61 & 93,8 & 3 & 4,6 & 0 & 0 & 1 & 1,5 & 30 & 27 & 90 & 3 & 10 & 0 & 0 & 0 & 0 \\
\hline & 6. Perubahan dalam pola tidur & 65 & 24 & 36,9 & 1 & 1,5 & 1 & 1,5 & 39 & 60 & 30 & 11 & 36,7 & 0 & 0 & 0 & 0 & 19 & 63,3 \\
\hline & 7. Nadi & 65 & 42 & 80 & 12 & 18,5 & 1 & 1,5 & 0 & 0 & 30 & 16 & 53,3 & 13 & 43,3 & 1 & 3,3 & 0 & 0 \\
\hline & 8. Pernafasan & 65 & 36 & 55,4 & 29 & 44,6 & 0 & 0 & 0 & 0 & 30 & 16 & 53,3 & 12 & 40,4 & 1 & 3,3 & 1 & 3,3 \\
\hline & 9. Status gizi & 65 & 6 & 9,2 & 47 & 72,3 & 2 & 3,1 & 10 & 15,4 & 30 & 2 & 6,7 & 12 & 40,4 & 6 & 20,2 & 10 & 33,3 \\
\hline & 10. Riwayat operasi & 65 & 0 & 0 & 0 & 0 & 0 & 0 & 65 & 100 & 30 & 0 & 0 & 0 & 0 & 0 & 0 & 19 & 63,3 \\
\hline & 11. Riwayat pengobatan & 65 & 6 & 9,2 & 0 & 0 & 0 & 0 & 59 & 90,8 & 30 & 1 & 3,3 & 0 & 0 & 1 & 3,3 & 28 & 29,3 \\
\hline & $\begin{array}{l}\text { 12. Riwayat merokok, } \\
\text { menggunakan narkoba dan } \\
\text { alkohol }\end{array}$ & 65 & 0 & 0 & 0 & 0 & 0 & 0 & 65 & 100 & 30 & 0 & 0 & 0 & 0 & 0 & 0 & 30 & 100 \\
\hline & $\begin{array}{l}\text { 13. Riwayat penyakit menular } \\
\text { seksual }\end{array}$ & 65 & 0 & 0 & 0 & 0 & 0 & 0 & 65 & 100 & 30 & 0 & 0 & 0 & 0 & 0 & 0 & 30 & 100 \\
\hline & 14. Riwayat alergi obat & 65 & 0 & 0 & 0 & 0 & 0 & 0 & 65 & 100 & 30 & 0 & 0 & 0 & 0 & 0 & 0 & 30 & 100 \\
\hline
\end{tabular}

Berikutnya berdasarkan pemeriksaan penunjang pada Tabel.3 pemanfaatan informasi rekam medis sesuai klaim dengan skor 4 keterangan "ya" berturut turut sebagai berikut: tes darah $(44,6 \%)$, uji tubex $(30,8 \%)$, tes widal $(10,8 \%)$ dan tes urin $(7,7 \%)$. Sedangkan dokumen yang tidak sesuai klaim yaitu: tes darah $(26,7 \%)$, tes widal $(13,3 \%)$, uji tubex $(10 \%)$ dan tes urin (3,3\%). Untuk skor 3 keterangan "bukan kasus ini" pada dokumen sesuai klaim, persentase tertinggi yaitu tes darah sebesar $20 \%$ dan terendah tes feses sebesar $1,5 \%$. Dokumen tidak sesuai klaim yaitu tes darah sebesar 33,3\% dan uji tubex sebesar 10\%. Untuk skor 2 keterangan "tidak" persentase 3,1\% yaitu uji tubex. Untuk skor 1 keterangan "TAK" persentase tertinggi tes feses sebesar $98,5 \%$ tes feses,

Tabel.3 Persentase Hasil Analisis Kualitatif Medis berdasarkan Pemeriksaan Penunjang pada Kasus Thypoid tahun 2016

\begin{tabular}{|c|c|c|c|c|c|c|c|c|c|c|c|c|c|c|c|c|c|c|c|}
\hline \multirow{3}{*}{ No. } & \multirow{3}{*}{ Pemeriksaan penunjang } & \multirow{3}{*}{$\mathbf{n}$} & \multicolumn{8}{|c|}{ Sesuai klaim } & \multirow{3}{*}{$\mathbf{n}$} & \multicolumn{8}{|c|}{ Tidak sesuai klaim } \\
\hline & & & \multicolumn{2}{|c|}{ Ya (4) } & \multicolumn{2}{|c|}{$\begin{array}{l}\text { Bukan } \\
\text { kasus ini } \\
\text { (3) }\end{array}$} & \multicolumn{2}{|c|}{$\begin{array}{c}\text { Tidak } \\
\text { (2) }\end{array}$} & \multicolumn{2}{|c|}{ TAK (1) } & & \multicolumn{2}{|c|}{ Ya (4) } & \multicolumn{2}{|c|}{$\begin{array}{l}\text { Bukan } \\
\text { kasus ini } \\
\text { (3) }\end{array}$} & \multicolumn{2}{|c|}{$\begin{array}{c}\text { Tidak } \\
\text { (2) }\end{array}$} & \multicolumn{2}{|c|}{ TAK (1) } \\
\hline & & & f & $\%$ & f & $\%$ & $\mathbf{f}$ & $\%$ & f & $\%$ & & f & $\%$ & f & $\%$ & f & $\%$ & f & $\%$ \\
\hline & 1. Tes urin & 65 & 5 & 7,7 & 4 & 6,2 & 0 & 0 & 56 & 86,2 & 30 & 1 & 3,3 & 0 & 0 & 4 & 13,3 & 25 & 83,3 \\
\hline & 2. Tes feses & 65 & 0 & 0 & 1 & 1,5 & 0 & 0 & 64 & 98,5 & 30 & 0 & 0 & 0 & 0 & 0 & 0 & 30 & 100 \\
\hline & 3. Tes darah & 65 & 29 & 44,6 & 13 & 20 & 0 & 0 & 23 & 35,4 & 30 & 8 & 26,7 & 10 & 33,3 & 6 & 20 & 6 & 20 \\
\hline & 4. Tes widal & 65 & 7 & 10,8 & 2 & 3,1 & 0 & 0 & 56 & 86,2 & 30 & 4 & 13,3 & 0 & 0 & 1 & 3,3 & 25 & 83,3 \\
\hline & 5. Uji tubex & 65 & 20 & 30,8 & 10 & 15,4 & 2 & 3,1 & 33 & 50,8 & 30 & 3 & 10 & 3 & 10 & 2 & 6,7 & 22 & 73,3 \\
\hline
\end{tabular}


Berdasarkan perawatan dan pengobatan pada Tabel.4 menunjukkan bahwa pemanfaatan informasi rekam medis sesuai klaim dengan skor 4 keterangan "ya" secara berurutan 3 tertinggi persentasenya yaitu cairan elektrolit (100\%), pemberian paracetamol $(98,5 \%)$, tirah baring $(96,9 \%)$. Dokumen tidak sesuai klaim persentase tertinggi tirah baring sebesar 100\%. Untuk skor 3 keterangan "bukan kasus ini" pada dokumen sesuai klaim yaitu 7,7\% diet kalori dan protein serta 4,6\% mobilisasi. Untuk skor 2 keterangan "tidak" yaitu mobilisasi sebesar 4,6\% dan pemberian kloramfenikol, paracetamol, jadwal kontrol masing-masing sebesar 1,5\% Untuk skor 1 keterangan "TAK" persentase tertinggi yaitu mengenai ruang perawatan sebesar 78,5\% dan terendah pendokumentasian perawat sebesar $1,5 \%$. Dokumen tidak sesuai klaim persentase tertinggi yaitu diet kalori dan protein yaitu sebesar $80 \%$,.

Tabel.4 Persentase Persentase Hasil Analisis Kualitatif Medis berdasarkan pengobatan dan perawatan pada Kasus Thypoid tahun 2016

\begin{tabular}{|c|c|c|c|c|c|c|c|c|c|c|c|c|c|c|c|c|c|c|c|}
\hline \multirow{3}{*}{ No. } & \multirow{3}{*}{ Perawatan dan pengobatan } & \multirow{3}{*}{$\mathbf{n}$} & \multicolumn{8}{|c|}{ Sesuai klaim } & \multirow{3}{*}{ n } & \multicolumn{8}{|c|}{ Tidak sesuai klaim } \\
\hline & & & \multicolumn{2}{|c|}{ Ya (4) } & \multicolumn{2}{|c|}{$\begin{array}{c}\text { Bukan } \\
\text { kasus ini } \\
(3)\end{array}$} & \multicolumn{2}{|c|}{$\begin{array}{c}\text { Tidak } \\
\text { (2) }\end{array}$} & \multicolumn{2}{|c|}{ TAK (1) } & & \multicolumn{2}{|c|}{ Ya (4) } & \multicolumn{2}{|c|}{$\begin{array}{c}\text { Bukan } \\
\text { kasus ini } \\
(3)\end{array}$} & \multicolumn{2}{|c|}{$\begin{array}{c}\text { Tidak } \\
\text { (2) }\end{array}$} & \multicolumn{2}{|c|}{ TAK (1) } \\
\hline & & & f & $\%$ & f & $\%$ & f & $\%$ & f & $\%$ & & f & $\%$ & f & $\%$ & f & $\%$ & f & $\%$ \\
\hline & 1. Pendokumentasian perawatan & 65 & 64 & 98,5 & 0 & 0 & 0 & 0 & 1 & 1,5 & 30 & 20 & 66,7 & 0 & 0 & 1 & 3,3 & 9 & 30 \\
\hline & 2. Ruang perawatan & 65 & 14 & 21,5 & 0 & 0 & 0 & 0 & 51 & 78,5 & 30 & 7 & 23,3 & 0 & 0 & 0 & 0 & 23 & 76,6 \\
\hline & 3. Tirah baring & 65 & 63 & 96,9 & 0 & 0 & 0 & 0 & 2 & 3,1 & 30 & 30 & 100 & 0 & 0 & 0 & 0 & 0 & 0 \\
\hline & 4. Mobilisasi & 65 & 37 & 56,9 & 3 & 4,6 & 3 & 4,6 & 22 & 33,8 & 30 & 9 & 30 & 0 & 0 & 1 & 3,3 & 20 & 66,7 \\
\hline & 5. Cairan elektrolit & 65 & 65 & 100 & 0 & 0 & 0 & 0 & 0 & 0 & 30 & 30 & 100 & 0 & 0 & 0 & 0 & 0 & 0 \\
\hline & 6. Diet kalori dan protein & 65 & 27 & 41,5 & 5 & 7,7 & 0 & 0 & 33 & 50,8 & 30 & 6 & 20 & 0 & 0 & 0 & 0 & 24 & 80 \\
\hline & 7. Obat kloramfenikol & 65 & 46 & 70,8 & 0 & 0 & 1 & 1,5 & 18 & 27,7 & 30 & 17 & 43,3 & 0 & 0 & 0 & 0 & 17 & 56,7 \\
\hline & 8. Obat paracetamol & 65 & 64 & 98,5 & 0 & 0 & 1 & 1,5 & 0 & 0 & 30 & 30 & 100 & 0 & 0 & 0 & 0 & 0 & 0 \\
\hline & 9. Jadwal kontrol & 65 & 53 & 81,3 & 0 & 0 & 1 & 1,5 & 11 & 16,9 & 30 & 20 & 66,7 & 0 & 0 & 7 & 23,3 & 3 & 10 \\
\hline & 10. Pendarahan usus & 65 & 0 & 0 & 0 & 0 & 0 & 0 & 65 & 100 & 30 & 1 & 3,3 & 0 & 0 & 0 & 0 & 29 & 96,7 \\
\hline & 11. Hepatitis tifosa & 65 & 4 & 6,2 & 0 & 0 & 0 & 0 & 61 & 93,8 & 30 & 1 & 3,3 & 0 & 0 & 0 & 0 & 29 & 96,7 \\
\hline
\end{tabular}

Berdasarkan komplikasi pada Tabel.5 bahwa pemanfaatan informasi rekam medis sesuai klaim dengan skor 4 keterangan "ya" persentase hepatitis tifosa sebesar 6,2\%. Untuk skor 1 keterangan "TAK" persentase $100 \%$ perdarahan usus dan hepatitis tifosa sebesar $93,8 \%$.

Tabel.5 Persentase Persentase Hasil Analisis Kualitatif Medis berdasarkan Komplikasi pada Kasus Thypoid tahun 2016

\begin{tabular}{|c|c|c|c|c|c|c|c|c|c|c|c|c|c|c|c|c|c|c|c|}
\hline \multirow{3}{*}{ No. } & \multirow{3}{*}{ Komplikasi } & \multirow{3}{*}{$\mathbf{n}$} & \multicolumn{8}{|c|}{ Sesuai klaim } & \multicolumn{9}{|c|}{ Tidak sesuai klaim } \\
\hline & & & \multicolumn{4}{|c|}{$\begin{array}{c}\text { Bukan } \\
\text { kasus ini } \\
\text { (3) }\end{array}$} & \multicolumn{2}{|c|}{$\begin{array}{l}\text { Tidak } \\
\text { (2) }\end{array}$} & \multicolumn{2}{|c|}{ TAK (1) } & \multirow[t]{2}{*}{$\mathbf{n}$} & \multicolumn{2}{|c|}{ Ya (4) } & \multicolumn{2}{|c|}{$\begin{array}{c}\text { Bukan } \\
\text { kasus ini } \\
(3)\end{array}$} & \multicolumn{2}{|c|}{$\begin{array}{c}\text { Tidak } \\
\text { (2) }\end{array}$} & \multicolumn{2}{|c|}{ TAK (1) } \\
\hline & & & f & $\%$ & f & $\%$ & f & $\%$ & f & $\%$ & & f & $\%$ & f & $\%$ & f & $\%$ & f & $\%$ \\
\hline 1. & Pendarahan usus & 65 & 0 & 0 & 0 & 0 & 0 & 0 & 65 & 100 & 30 & 1 & 3,3 & 0 & 0 & 0 & 0 & 29 & 96,7 \\
\hline 2. & Hepatitis tifosa & 65 & 4 & 6,2 & 0 & 0 & 0 & 0 & 61 & 93,8 & 30 & 1 & 3,3 & 0 & 0 & 0 & 0 & 29 & 96,7 \\
\hline
\end{tabular}

Berdasarkan proses klaim pada Tabel.6, menunjukkan bahwa pemanfaatan informasi rekam medis sesuai klaim dengan skor 4 keterangan "ya" persentase tertinggi sebesar $100 \%$ pada resume medis dan diagnosa utama. Untuk skor 3 keterangan "bukan kasus ini" sebesar $60 \%$ diagnosa sekunder menjadi diagnosa utama. Untuk skor 2 keterangan "tidak" sebesar 7,7\% terkait pemeriksaan penunjang lain. Untuk skor 1 keterangan "TAK" persentase tertinggi masing-masing sebesar $100 \%$ yaitu: surat perintah rawat inap, surat elegebitas peserta, laporan operasi dan yang terendah lama perawatan sebesar 1,5\%. 
Tabel.6 Persentase Hasil Analisis Kualitatif Medis berdasarkan Proses Klaim pada Kasus Thypoid tahun 2016

\begin{tabular}{|c|c|c|c|c|c|c|c|c|c|c|c|c|c|c|c|c|c|c|c|}
\hline \multirow{3}{*}{ No. } & \multirow{3}{*}{ Proses klaim } & \multirow{3}{*}{$\mathbf{n}$} & \multicolumn{8}{|c|}{ Sesuai klaim } & \multirow{3}{*}{$\mathbf{n}$} & \multicolumn{8}{|c|}{ Tidak sesuai klaim } \\
\hline & & & \multicolumn{2}{|c|}{ Ya (4) } & \multicolumn{2}{|c|}{$\begin{array}{l}\text { Bukan } \\
\text { kasus ini } \\
\text { (3) }\end{array}$} & \multicolumn{2}{|c|}{$\begin{array}{l}\text { Tidak } \\
(2)\end{array}$} & \multicolumn{2}{|c|}{ TAK (1) } & & \multicolumn{2}{|c|}{ Ya (4) } & \multicolumn{2}{|c|}{$\begin{array}{c}\text { Bukan } \\
\text { kasus ini } \\
\text { (3) }\end{array}$} & \multicolumn{2}{|c|}{$\begin{array}{c}\text { Tidak } \\
\text { (2) }\end{array}$} & \multicolumn{2}{|c|}{ TAK (1) } \\
\hline & & & f & $\%$ & f & $\%$ & f & $\%$ & f & $\%$ & & f & $\%$ & f & $\%$ & $\mathbf{f}$ & $\%$ & f & $\%$ \\
\hline 1. & Surat perintah rawat inap & 65 & 0 & 0 & 0 & 0 & 0 & 0 & 65 & 100 & 30 & 0 & 0 & 0 & 0 & 0 & 0 & 30 & 100 \\
\hline 2. & Surat eligibilitas peserta & 65 & 0 & 0 & 0 & 0 & 0 & 0 & 65 & 100 & 30 & 0 & 0 & 0 & 0 & 0 & 0 & 30 & 100 \\
\hline 3. & Resume medis & 65 & 65 & 100 & 0 & 0 & 0 & 0 & 0 & 0 & 30 & 29 & 96,7 & 0 & 0 & 0 & 0 & 1 & 3,3 \\
\hline 4. & Diagnosa utama & 65 & 65 & 100 & 0 & 0 & 0 & 0 & 0 & 0 & 30 & 30 & 100 & 0 & 0 & 0 & 0 & 0 & 0 \\
\hline \multirow[t]{3}{*}{5.} & Diagnosa & & & & & & & & & & & & & & & & & & \\
\hline & a. Diagnosa sekunder & 65 & 42 & 64,6 & 0 & 0 & 0 & 0 & 23 & 5,4 & 30 & 19 & 63,3 & 0 & 0 & 1 & 3,3 & 10 & 33,3 \\
\hline & $\begin{array}{l}\text { b. Diagnosa sekunder menjadi } \\
\text { utama }\end{array}$ & 65 & 2 & 31,2 & 39 & 60 & 0 & 0 & 24 & 36,9 & 30 & 1 & 3,3 & 18 & 60 & 0 & 0 & 11 & 36,7 \\
\hline 6. & Pemeriksaan penunjang utama & 65 & 55 & 84,6 & 0 & 0 & 0 & 0 & 10 & 15,4 & 30 & 24 & 80 & 0 & 0 & 0 & 0 & 6 & 20 \\
\hline 7. & Pemeriksaan penunjang lain & 65 & 16 & 24,6 & 33 & 50,8 & 5 & 7,7 & 11 & 16,9 & 30 & 10 & 33,3 & 14 & 46,7 & 0 & 0 & 6 & 20 \\
\hline 8. & Lama perawatan & 65 & 64 & 98,5 & 0 & 0 & 0 & 0 & 1 & 1,5 & 30 & 29 & 96,7 & 0 & 0 & 0 & 0 & 1 & 3,3 \\
\hline 9. & Laporan operasi & 65 & 0 & 0 & 0 & 0 & 0 & 0 & 65 & 100 & 30 & 1 & 3,3 & 0 & 0 & 0 & 0 & 29 & 96,7 \\
\hline
\end{tabular}

\section{PEMBAHASAN}

\section{Analisis Kualitatif Administratif Kelengkapan Informasi Dokumen Rekam Medis Kasus Thypoid tahun 2016}

Hasil pencatatan informasi tentang kejelasan masalah dan kondisi atau diagnosis pada dokumen rekam medis di rumah sakit Jasa Kartini adanya kesesuaian antara informasi dari pasien dengan tidakan yang diberikan. Pencatatan tersebut terbukti dengan hasil pemeriksaan suhu dan pemeriksaan fisik karena pasien mempunyai keluhan khas thypoid kemudian dilakukan pemeriksaan yang menunjang penentuan diagnosis. Hal ini sejalan dengan hasil penelitian Hatta (2015) dalam Analisis Kelengkapan dan Pemanfaatan Pendokumentasian Rekam Kesehatan Ortotik Prostetik tentang kejelasan dan masalah dan kondisi/diagnosis dengan jawaban lengkap sebanyak 93\% artinya rekaman telah memuat dasar dasar berobat yang jelas dengan kondisi/diagnosis pasien. Menururt teori Hatta (2013) kejelasan masalah dan kondisi atau diagnosis yaitu adanya hubungan yang jelas antara informasi dari pasien dengan tindakan yang dilakukan.

Berikutnya tentang konsistensi menunjukkan bahwa dalam pencatatan informasi telah konsisten dengan kondisi informasi mengenai keluhan ataupun masalah pasien, catatan tersebut terbukti dengan adanya hasil pemeriksaan suhu. Hal ini sejalan dengan hasil penelitian Rahmawati (2014) dalam Analisa Kuantitatif Dan Kualitatif Dokumen Rekam
Medis Rawat Inap Kasus Bedah Pada Tindakan Hernioraphy Di Rsud Tugurejo Semarang Pada Triwulan I Tahun 2014 dengan ketidaklengkapan tertinggi terdapat pada review kelengkapan dan pencatatan kekonsistensian diagnosa, perawatan dan pengobatan yaitu 37 DRM (73\%) lengkap dan 14 DRM (27\%) tidak lengkap/tidak konsisten dalam pencatatan diagnosa. Menurut teori Hatta (2013) masukan konsisten adalah adanya hubungan antara data dalam dokumen dengan informasi tentang kondisi pasien. Konsistensi menunjukkan bahwa pelayanan yang diberikan kepada pasien sudah jelas alasan yang mendasarinya dipearkuat dengan hasil keterangan "tidak" lebih rendah dengan persentase $1,5 \%$ untuk dokumen sesuai klaim dan 3,3\% untuk dokumen tidak sesuai klaim. Sejalan pada penelitian Hatta (2015) dalam analisis kelengkapan pendokumentasian Ortotik Prostetik menyebutkan bahwa apabila ketiga unsur yaitu kejelasan masalah dan kondisi, masukan konsisten dan alasan pelayanan lebih lengkap itu menunjukkan cukup menjelaskan alasan pasien mendatangi layanan kesehatan memang setara dengan kondisinya. Setiap pasien yang diduga menderita penyakit typhoid akan dilakukan pemeriksaan widal untuk menegakkan diagnosis thypoid. Menurut Tjokroprawiro (2007) tes widal dilakukan untuk mengetahui kenaikan O tinggi atau kenaikan titer 4 kali lipat dengan jarak waktu 7 hari pemeriksaan pertama dan kedua (O lebih spesifik dari H). Selanjutnya bila hasil menunjukkan positif terkena typhoid, menurut Nelwan (2012) maka harus 
diberikan obat Chloramphenicol dan sudah menjadi terapi standar pada demam thypoid.

Berikutnya tentang pengisian informed consent bukan hanya untuk pemberian tindakan khusus namun untuk keseluruhan tindakan yang akan diberikan kepada pasien seperti pemasangan infus, berdasarkan tabel.1 pengisian informed consent dengan persentase $100 \%$ untuk dokumen yang sesuai klaim dan dokumen tidak sesuai klaim dinyatakan sudah lengkap yaitu adanya pencatatan diagnosis, tata cara tindakan medis, tujuan dan resiko dari tindakan, Hal tersebut sejalan dengan hasil penelitian Rahmawati (2014) dalam Analisa Kuantitatif Dan Kualitatif Dokumen Rekam Medis Rawat Inap Kasus Bedah Pada Tindakan Hernioraphy untuk reviewinformed consent menunjukkan 47 (92\%) lengkap dan $4(8 \%)$ tidak lengkap karena tidak terdapat tanda tangan pasien dan dokter pemberi informasi. Menurut Hatta (2013) bahwa informed consent merupakan pernyataan persetujuan sepihak atas layanan yang ditawarkan pihak lain, dengan demikian harus ditandatangani oleh pasien atau keluarga pasien sebagai bukti persetujuan, sedangkan pihak rumah sakit termasuk dokter hanya menjadi saksi. Berdasarkan Permenkes 290 tahun 2008 tentang persetujuan tindakan kedokteran pasal 1 ayat 5 Informed consent sebagai bukti dikemudian hari apabila dilakukannya tindakan yang beresiko tinggi berdasarkan probabilitas tertentu mengakibatkan kematian atau kecacatan.

Selanjutnya terkait unsur mutakhir berdasarkan tabel. 1 terdapat $100 \%$ artinya pencatatan di rumah sakit Jasa Kartini sudah sesuai dengan dicatat segera setelah dilakukan pemeriksaan. Menurut Hatta (2013) bahwa mutakhir yaitu pencatatan segera dilakukan setelah pemeriksaan/pemberian pelayanan tanpa ada pencatatan yang dilakukan hingga hari berikunya.

Wariyanti \& Sugiarsi(2019); dalam melakukan pencatatan laporan teritama pencatatan tanggal dan jam harus diisi segera, pencatatan menjadi penting karena ada kaitannya dengan peraturan bahwa pencatatan rekam medis harus dilengkapi selambat-lambatnya dalam waktu $1 \times 24$ jam. Tata cara pendokumentasian merupakan unsurunsur atau syarat yang harus dipenuhi dalam mendokumentasikan data pelayanan dalam rekam medis pasien. Tata cara pendokumentasian ini harus dipenuhi dan dilaksanakan oleh setiap petugas yang berwenang mengisi rekam medis, sehingga dapat mendukung terciptanya rekam medis yang baik dan lengkap dari segi penulisannya.
Terkait singkatan baku menunjukkan masih terdapat sedikit yang menggunakan singkatan tidak baku, Hal ini berarti perlu peningkatan keilmuan dan keterampilan berikutnya dalam penggunaan peristilahan medis yang sudah disepakati dalam dunia kesehatan atau sarana pelayanan kesehatan. Selain itu isinya tidak ada catatan yang menjatuhkan sesama rekan sejawat serta pencatatan yang di lakukan di rumah sakit Jasa Kartini dilakukan setiap pasien datang tanpa adanya kekosongan meski dalam keadaan darurat akan tetapi masih ada catatan yang masih senjang artinya adanya baris yang kosong antara setiap baris harus dihindari karena kesenjangan bisa berisiko munculnya tulisan data atau informasi ilegal (palsu) yang bukan hasil penulisan petugas itu sendiri (pemberi pelayanan kesehatan). Penggunaan tinta juga sudah sesuai yaitu menggunakan tinta warna biru atau hitam dalam penulisan, khusus untuk suhu, nadi, pernafasan boleh menggunakan warna merah dan hijau. Berdasarkan hasil analisis pada dokumen sesuai klaim catatan sudah lengkap namun pada dokumen tidak sesuai klaim catatan belum lengkap dengan persentase 66,7\% lengkap dan 33,3\% tidak lengkap artinya dalam dokumen rekam medis tidak ditulis secara urutan kronologinya oleh pemberi pelayanan. Catatan yang tidak lengkap ditemukan dalam formulir asal masuk pasien rawat inap, catatan tersebut dapat dimuat dalam formulir IGD atau rawat jalan. Formulir tersebut di rumah sakit Jasa Kartini dapat memberi keterangan pertama pasien masuk, hal tersebut menyebabkan tidak teruntutnya kronologis pasien. Hal ini sejalan dengan hasil penelitian Utami, dll(2016) tentang kelengkapan pencatatan perawat yang menyatakan kelengkapan catatan keperawatan dibagi menjadi dua yaitu data administratif sebesar $87,8 \%$, sedangkan data klinis sebesar 95,5\% diperkuat dengan wawancara bahwa perawat tidak mengisi secara lengkap dikarenakan banyaknya beban kerja. Berdasarkan Permenkes nomor 269 tahun 2008 tentang rekam medis pasal 3 tercantum bahwa rekam medis harus segera dilengkapi setelah melakukan pelayanan atau tindakan dan disertai nama, waktu dan tanda tangan dokter.

Berdasarkan Hatta (2013) kelengkapan informasi rekam medis berdasarkan urutan kronologis sesuai tahapan kunjungan dan pemberian pelayanan kesehatan sehingga informasi medis jelas dan mudah dipahami. Berikutnya persentase terkait informasi ganti rugi mempunyai nilai lebih tinggi pada keterangan "tidak" karena tidak adanya informasi ganti rugi dalam dokumen pasien. Hasil analisis yang dilakukan tidak ditemukan dalam dokumen 
sesuai klaim maupun tidak sesuai klaim bahwa pasien menderita thypoid diakibatkan oleh pekerjaannya, maka persentase keterangan "tidak" didapatkan $100 \%$ sebab tidak ada informasi ganti rugi. Menurut teori Hatta (2013) bila kondisi atau penyakit pasien memerlukan ganti rugi misalnya akibat resiko kerja yang merugikan pasien atau bila keadaan sekarang mendapat pengganti biaya berobat. Berbeda dengan informasi penanggung biaya di rumah sakit Jasa Kartini tergambarkan sudah sesuai dengan persentase $100 \%$, dimana informasi adanya penanggung biaya pada catatan penanggung biaya baik pasien umum maupun asuransi dalam formulir ringkasan masuk dan keluar.

\section{Analisis Kualitatif Medis Kelengkapan Informasi Dokumen Rekam Medis Kasus Thypoid tahun 2016P}

Pencatatan keluhan thypoid secara umum sudah lengkap dan infromasi ekstra sebagai tindak lanjut dari informasi tentang keluhan sudah ada seperti dengan adanya pemeriksaaan nadi, pernapasan, suhu untuk penegakkan diagnosa dilakukan pemeriksan darah dan widal. Pemeriksaan tersebut sejalan dengan gejala yang dirasakan oleh pasien dalam kelengkapan informasi ekstra terdapat 93,8\% dan 10\%. Sejalan dengan hasil penelitian Inawati (2015) tentang demam tyfoid menyatakan adanya keluhan pada awal minggu yang dirasakan demam tinggi yang berpanjangan yaitu setinggi $39^{\circ} \mathrm{c}$ hingga $40^{\circ} \mathrm{c}$, sakit kepala, pusing, pegal-pegal, anoreksia, mual, muntah. Menurut teori Hatta (2013) informasi ekstra menandakan pasien dengan komplikasi atau kondisi buruk atau beresiko telah ditindak lanjuti oleh tenaga kesehatan. Keterangan "bukan kasus ini" dengan skor 3 tertinggi pada dokumen sesuai klaim 78,5\% adalah usia pasien sebanding dengan dokumen yang tidak sesuai klaim 76,7\%, menurut teori Rampengan (2008) umur penderita yang terkena di Indonesia (daerah endemis) dilaporkan antara 3-19 tahun mencapai 91\% kasus. Dengan persentase tersebut informasi ekstra bahwa pasien yang berada di usia 3-19 tahun rata-rata terkena thypoid sedangkan di bawah usia 3 tahun tidak ditemukannya kasus terkena thypoid.

Berdasarkan keterangan "tidak" skor 2 tertinggi dengan persentase 3,1\% sesuai klaim dan 20\% tidak sesuai klaim pada pernyataan status gizi, dalam dokumen rekam medis di rumah sakit Jasa Kartini terdapat formulir khusus untuk penilaian gizi, anjuran terdapat dan dilakukannya pemeriksaan namun hasil dari pemeriksaan tidak tercantum dalam dokumen. Hal ini menandakan pengisian tidak lengkap oleh pemberi pelayanan. Berdasarkan Kepmenkes nomor 346 tahun 2006 bahwa penilaian gizi dilakukan sebab transmisi utama basil salmonella melalui air dan makanan. Berdasarkan pasal 46 ayat (1) UU Praktik Kedokteran tahun 2009 menegaskan bahwa dokter dan dokter gigi wajib membuat rekam medis dalam menjalankan praktik kedokteran setelah memberikan pelayanan segera melengkapi rekam medis. Hal ini menjadi penilaian kelengkapan untuk mengetahui sejauh apa kualitas pelayanan yang diberikan kepada pasien.

Pemanfaatan informasi dari keluhan pasien secara klinis telah ditindaklanjuti dengan pemeriksaan penunjang tes darah termasuk didalamnya tes widal serta dilakukan uji tubex. Hal ini dapat menggambarkan bahwa penegakkan diagnosa perlu adanya pemeriksaan penunjang, dan untuk pencegahan komplikasi yang timbul dan tergambarnya tertibnya kelengkapan informasi tentang tindak lanjut. Menurut teori Tjokroprawiro (2007) tes darah dilakukan untuk pencegahannya leukopenia, leukositosit dan anemia. Menurut teori Nelwan (2012) tes widal digunakan untuk mendeteksi antibodi terhadap antigen salmonella thypy dan menurut teori Sudoyo (2010) uji tubex digunakan untuk mendeteksi anti S.thypi. Dalam pencatatan dokumen yang tidak sesuai klaim masih ada sedikit terlihat ketidaklengkapan dalam pencatatan hasil pemeriksaan penunjang, hal ini diartikan dokumen tidak segera dilengkapi oleh pemberi pelayanan.

Pemanfaatan infomasi tentang pengobatan dan perawatan yang tertinggi terkait pendokumentasian keperawatan dan pemberian obat paracetamol untuk dokumen sesuai klaim dan untuk dokumen tidak sesuai klaim yaitu pemberian cairan elektrolit, tirah baring, pemberian paracetamol. Hal ini mengambarkan adanya pengisian informasi ekstra yang lengkap, sejalan dengan teori Nelwan (2012) bahwa pemberian obat paracetamol untuk menurunkan demam sebagai terapi untuk mencegah komplikasi dan kekambuhan penyakit tersebut. Terdapat keterangan "tidak" skor 2 tertinggi pada mobilisasi dan jadwal kontrol serta pada pengisian jadwal tidak lengkapnya pengisian nama dan tanda tangan dokter. Berdasarkan Permenkes 269 tahun 2008 tentang rekam medis bahwa setiap isian dokumen harus disertai nama dan tanda tangan dokter atau dokter gigi yang memberikan pelayanan. Menurut teori Nelwan (2012) jadwal kontrol sebagai upaya pencegahan seiring munculnya 
kasus resistensi. Terdapat juga keterangan "TAK" dengan skor 1 tertinggi pada dokumen sesuai klaim pada pernyataan ruang perawatan, dikarenakan tidak ada keterangan pasien membutuhkan ruang khusus terpisah dari pasien lainnya dan tidak adanya keterangan anjuran untuk diet.

Selanjutnya pemanfaatan infomasi tentang komplikasi pada keterangan "TAK" dengan perdarahan usus dan hepatitis tifosa dikarenakan tidak adanya keterangan atau informasi ekstra pasien mengalami komplikasi. Menurut Sudoyo(2010) bahwa kasus hepatitis tifosa dapat terjadi pada pasien dengan malnutrisi dan sistem imun yang kurang dan menurut Rampengan (2008) menyebutkan bahwa kasus perdarahan usus terjadi akibat penurunan tekanan darah dan nyeri perut serta penegakkan diagnosa ditunjang dengan hasil USG.

Berikutnya terkait proses klaim diperlukan kelengkapan pengisian rekam medis seperti lama perawatan, resume medis, diagnosa utama, diagnosa sekunder dan tindakan yang dilakukan, pemeriksaan penunjang. Kelengkapan dokumen dengan berkas yang di klaim kepada BPJS harus lengkap mengingat tahapan verifikasi melalui beberapa tahap. Menurut BPJS (2014) bahwa pengisian resume medis harus memuat diagnosa utama, sekunder dan tindakan yang dilakukan sesuai dengan diagnosa sehingga tarif akan sesuai jika dokumen lengkap. Selain itu, adanya pemeriksaan penunjang yang tidak mendukung terhadap diagnosa utama sehingga dapat menyebabkan tarif sesuai klaim dan tidak sesuai klaim (rugi) hal ini diperkuat sebab adanya penurunan jaminan dari diagnosa utama yang menjadikan diagnosa sekunder sebagai utama, hal ini dapat menyebabkan kerugian sebab pemeriksaan penunjang tidak mendukung diagnosa tersebut.

Hal ini, sejalan dengan penelitian Ulfah (2011) dalam kelengkapan persetujuan klaim menyatakan bahwa dari 85 dokumen rekam medis yang lengkap dengan prosentase 90,4\%, sedangkan dokumen rekam medis yang tidak lengkap ada 9 dengan prosentase 9,6\%. faktor yang terbesar mempengaruhi klaim tidak disetujui karena faktor hasil pemeriksaan penunjang yang belum lengkap. Dalam penegakkan diagnosa dokter sudah berdasarkan hasil-hasil pemeriksaan penunjang yang ada, namun kode diagnosa yang ditegakkan oleh dokter tidak sesuai dengan hasil pemeriksaan penunjang. Menurut BPJS (21014) bahwa perlunya konfirmasi administrasi pelayanan dengan meminta bukti penunjang yang diperlukan untuk klaim sesui dengan diagnosa utama. Keterangan "tidak" (skor 2) pada pernyataan pemeriksaan penunjang, hal ini karena pemeriksan dilakukan untuk menegakkan diagnosa lain tetapi tidak ada informasi ekstra hasil dari pemeriksaannya tersebut. Keterangan "TAK" tertinggi skor 1 persentase $100 \%$ dikarenakan tidak adanya kelengkapan berkas surat perintah rawat inap dan surat elegebitas peserta karena surat ini hanya dicetak sekali dan tidak disimpan dalam dokumenm, terpisah hanya untuk proses kelengkapan berkas klaim ke BPJS. Proses pengajuan pengklaiman dari rumah sakit kepada BPJS harus sesuai dengan prosedur pengklaiman yang telah ditetapkan oleh BPJS baik persyaratan maupun waktu, hal itu sangat penting karena akan mempengaruhi hasil verifikasi yang dikeluarkan oleh BPJS dan berdampak terhadap pendapatan rumah sakit.

\section{SIMPULAN}

Kelengkapan pengisian mendekati 100\% terjadai pada kejelasan kondisi atau diagnosis, masukan konsisten, alasan pelayanan, informed consent, telaah rekaman serta informasi penanggung biaya dengan hasil sebagian besar menunjukkan persentase ratarata tinggi namun masih terdapat ketidaklengkapan di beberapa unsur. Penilaian kasus typhoid sudah sesuai dengan tatalaksana thypoid dilihat dari kelengkapan catatan mengenai keluhan dan gejala, pemeriksaan penunjang yang sesuai klaim lebih lengkap terkait dengan tes darah dan widal, Catatan pendokumentasian keperawatan dokumen sesuai klaim dari hasil analisis dinyatakan lebih lengkap, ditemukan komplikasi perporasi usus dan hepatitis tifosa dan proses klaim dilihat dari penilaian kelengkapan surat perintah rawat inap, SEP, Laporan operasi. Disarankan bagi dokter diharapkan agar menulis penentuan diagnosis dan pemeriksaan penunjang lebih teliti dan lebih lengkap

\section{DAFTAR PUSTAKA}

Abdullah, Hana. (2013). Analisis Kegiatan Pengelolaan Rekam Medis Rawat InapPasien Kanker Payudara Program Jamkesmas Untuk Mendukung Pengelolaan Pembiayaan Kesehatan di Rumah Sakit Islam Sultan Agung Semarang Tahun 2011.Tersedia http/ ejournal1.undip.ac.id/index.php/jkm [25 Januari 2017]. 
Alamsyah, Dedi (2011). Manajemen Pelayanan Kesehatan. Yogyakarta : Nuha medika.

Azwar, Azrul. (2010). Pengantar Administrasi Kesehatan. Tanggerang: Bina Aksara.

Badan Penyelenggara Jaminan Sosial. (2014). Panduan Layanan Bagi Peserta BPJS Kesehatan. Jakarta : Badan Penyelenggara Jaminan Sosial.

Departemen Kesehatan Republik Indonesia.(2006 ). Pedoman Penyelenggaraan Dan Prosedur Rekam Medis Rumah Sakit Di Indonesia. Jakarta:Direktorat Jenderal Bina Pelayanan Medik.

Dorland, W.A.Newman. (2014). Kamus Saku Kedokteran Dorland Edisi 28.

Jakarta: Buku Kedokteran EGC.

Hatta, Gemala. (2013). Pedoman Manajemen Informasi Kesehatan DisaranaPelayanan Kesehatan. Jakarta : Penerbit Universitas Indonesia.

Hatta, Gemala. (2015). Metoda Hatta untuk Analisis Kelengkapan dan Pemanfaatan Pendokumentasian Rekam Kesehatan Ortotik Prostetik. Tersedia http://www. poltekkesjakarta.ac.id [24 februari 2017].

Keputusan Menteri Kesehatan Republik Indonesia Nomor 364/MenteriKesehatan/SK/V/2006 Tentang Pedoman Pengendalian Demam Tifoid.Undang-Undang Republik Indonesia Nomor 44 Tahun 2009 Tentang RumahSakit.

Kementrian Kesehatan Republik Indonesia. (2011). Profil Kesehatan 2010: Kementrian Kesehatan Republik Indonesia.

Kementerian Kesehatan. (2013). Buku Pegangan Sosialisasi BPJS. Jakarta : Kementerian Kesehatan.

Malonda, T.D. et al (2015) Analisis Pengajuan Klaim Badan PenyelenggaraJaminan Sosial (BPJS) Kesehatan di RSUD Dr. Sam Ratulangi Tondano. Tersedia ejournal.unsrat.ac.id/index. php/jikmu [20 Februari2017].

Nuruzzaman, N \& Syahrul, F. (2016). Analisis Risiko Kejadian Demam Tifoid Berdasarkan Kebersihan diri dan Kebiasaan Jajan dirumah.Tersedia e-journal.unair.ac.id/index. php [02 Maret 2016].
Nelwan, HH. (2012). Tata Laksana Terkini Demam Tifoid. Tersedia

www.kalbemed.com [02 maret 2017].

Notoatmodjo, Soekidjo. (2010). Metodologi Penelitian Kesehatan. Jakarta: Rineka Cipta.

Peraturan Menteri Kesehatan Republik Indonesia Nomor 28.(2014).Tentang Pedoman Pelaksanaan Program Jaminan Kesehatan Nasional.

Perhimpunan Dokter Spesialis Penyakit Dalam. (2008). Panduan Pelayanan Medik : PB PAPDI.

Peraturan Presiden Republik Indonesia Nomor 12 Tahun 2013 Tentang Jaminan Kesehatan.

Peraturan Menteri Kesehatan Republik Indonesia Nomor 290 Tahun 2008 Tentang Persetujuan Tindakan Kedokteran.

Putra, Rendi Fadhlan.(2016).Analisis Manajemen Piutang Pendapatan Jasa Layanan Pada Rsud Dr. Soetomo.Tersedia http://digilib. binadarma.ac.id [22 Mei 2017]

Putri, Dita Nadira.(2016).Analisi Pengendalian Internal Pasa Siklus Pendapatan Dari Pasien Pengguna BPJS. Tersedia http://www. jurnalpost.com/klaim-bpjs-lambat-cairpengaruhi-pelayanan-rs [22 Mei 2017]

Rahmawati, Atika Rizky.(2014). Analisa Kuantitatif Dan Kualitatif Dokumen Rekam Medis Rawat Inap Kasus Bedah Pada Tindakan Hernioraphy Di Rsud Tugurejo Semarang Pada Triwulan I Tahun 2014. Tersedia http:// epirints.dinus.ac.id [02 Juni 2017]

Rampengan, T.H. (2008). Penyakit Infeksi Tropik Pada Anak. Jakarta : Penerbit Buku Kedokteran EGC.

Sudoyo, A.W. Et Al (2010). Buku Ajar Ilmu Penyakit Dalam. Jakarta : Interna Publishing.

Tjokroprawiro, Askandar. (2007). Buku Ajar Ilmu Penyakit Dalam. Subaya : Airlangga University.

Undang-Undang Republik Indonesia Nomor 40 Tahun 2004 Tentang Sistem Jaminan Sosial Nasional. 
Suci Khotimah dan Imas Masturoh. Analisis Kelengkapan Berkas Rekam Medis Pasien Rawat Inap ...

Undang-Undang Republik Indonesia Nomor 24 Tahun 2011 Tentang Badan Penyelenggara Jaminan Sosial.

Undang-Undang Republik Indonesia Nomor 46 Tahun 2009 Tentang Praktik Kedokteran.

Utami, Sri. Et Al(2016).Hubungan Tingkat Pengetahuan Tentang Rekam Medis Dengan Kelengkapan Pengisian Catatan Keperawatan Pada Instalasi Rawat Inap Di Rumah Sakit At-Turots Al Islamy Sleman. Tersedia http:// epirints.dinus.ac.id [02 Juni 2017]
Wariyanti, AS, Harjanti, Sugiarsi S(2019). Potret Kelengkapan Rekam Medis Puskesmas Sebelum dan Setelah Akreditasi. Jurnal Manajemen Informasi Kesehatan Indonesia(JMIKI. Vol.7 N0.2

Word Health Organitazion (WHO). (2011). Guidelines for the Management of Typhoid Fever. 